\title{
The monitoring experience of a congenital heart disease patient with pulmonary artery stenosis and "sluggish skin" syndrome
}

Rackhima Mekenbayeva $^{1}$, Shuhrat Marassulov ${ }^{1}$, Anar Sarsembayeva ${ }^{1}$, Bakhytzhan Nurkeyev ${ }^{1}$, Rinat Maiorov ${ }^{1}$, Daniyar Baigozhin ${ }^{2}$, Nigina Mekenbayeva ${ }^{3}$, Arman Akseitov A.M. ${ }^{3}$

'Pediatric Cardiac Surgery Department, National Scientific Medical Center, Nur-Sultan city, Republic of Kazakhstan

${ }^{2}$ Cardiology Department, National Scientific Medical Center, Nur-Sultan city, Republic of Kazakhstan

${ }^{3}$ Astana Medical University, Nur-Sultan city, Republic of Kazakhstan

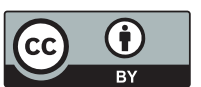

This work is licensed under a Creative Commons Attribution 4.0 International License

\section{Received: 2019-02-28}

Accepted: 2019-04-18

UDC: 616.1

\section{J Clin Med Kaz 2019; 2(52):63-67}

Corresponding Author: Rackhima Mekenbayeva, Pediatric Cardiac Surgery Department, National Scientific Medical Center. Address: 7\1, Mailin street, 010001 Nur-Sultan city, Republic of Kazakhstan. Tel: +7 705 485-75-81

E-mail: mrt.14@mail.ru

\section{Abstract}

This article presents a clinical case of the follow-up of a patient with a congenital heart defect in the form of the pulmonary artery stenosis in the setting of the "sluggish skin" syndrome. It is shown that the occurrence of congenital defects largely depends on the hereditary factor, which, in this case, is a related marriage. You should also pay attention to the fact that the associated congenital heart disease: the mouth of the pulmonary artery against the background of the "sluggish skin" syndrome spontaneously stopped without surgery, which is probably due to the peculiarity of the background disease, that is, generalized elastolysis. The natural course of this congenital heart defect against the background of a genetic pathology in the form of "sluggish skin" syndrome indicates the positive influence of the pathological substrate (connective tissue hyperelasticity) on the state of the tissues of the heart and blood vessels. Despite the already available data, it is still difficult to make a prediction of the course of this disease. For a better understanding of the course of this pathological process, further observation of the patient is necessary.

Keywords: sluggish skin syndrome, pulmonary stenosis, congenital heart defect

ӨКПЕ АРТЕРИЯСЫНЫН СТЕНОЗЫ ТУРІНДЕ ДАМЫҒАН «ӘЛСІЗ ТЕРІ ЖАМЫЛҒЫСЫ» СИНДРОМЫМЕН ТУА ПАЙДА БОЛҒАН ЖУРЕК АҚАУЫ БАР НАУҚАСТАРДЫ КАТАМНЕСТИКАЛЫҚ БАҚЫЛАУ ТӘЖІРИБЕСІ

Мекенбаева Р.Т. ${ }^{1}$, Марасулов Ш.И. ${ }^{1}$, Сәрсембаева А.А. ${ }^{1}$, Нұркеев Б.А. ${ }^{1}$, Майоров Р.А. ${ }^{1}$, Байғожин Д.М. ${ }^{2}$, Мекенбаева Н.Б. ${ }^{3}$, Ақсеитов А.M. ${ }^{3}$

'Балалар кардиохирургия бөлімі, Ұлттық ғылыми медициналық орталық, Нұр-Сұлтан қаласы, Қазақстан Республикасы

${ }^{2}$ Кардиология бөлімшесі, Ұлттық ғылыми медициналық орталық, Нұр-Сұлтан қаласы, Қазақстан Республикасы

${ }^{3}$ Астана медициналық университеті, Нұр-Сұлтан қаласы, Қазақстан Республикасы

\section{тҰЖЫРЫМдАМА}

Бұл мақалада «бос тері» синдромының фонында өкпе артериясының стенозы түрінде туа біткен жүрек ақауы бар науқастың клиникалық жағдайы келтірілген. Туа біткен ақаулардың пайда болуы көбінесе тұқым қуалайтын факторға байланысты, бұл жағдайда ол туысты некеге байланысты болып табылады. Сондай-ақ, туа біткен жүректің ақауы: өкпе артериясының тарылуы «бос тері» синдромының фонында өздігінен операциясыз қалпына келді, бұл фондық аурулардың ерекшелігіне, яғни, жалпыланған эластолизге байланысты болуы тиіс. «Бос тері» синдромы түріндегі генетикалық патологиясының жүрек ақауы патологиялық субстраттарына (дәнекер тіннің гиперэластиктивтілігін) жүрек және тамыр тіндеріне байланысты оң әсерін көрсетті. Бар деректерге қарамастан, осы аурудың барысын болжау әлі де қиын. Осы патологиялық үрдістің барысын жақсы түсіну үшін науқасты одан әрі бақылау қажет.

Негізгі сөздер: «бос тері» синдромы, өкпе артериясының стенозы, туа біткен жүрек кемістігі 


\section{ОПЫТ КАТАМНЕСТИЧЕСКОГО НАБЛЮДЕНИЯ ЗА ПАЦИЕНТОМ С ВРОЖДЕННЫМ ПОРОКОМ СЕРДЦА В ВИДЕ}

СТЕНОЗА ЛЕГОЧНОЙ АРТЕРИИ НА ФОНЕ СИНДРОМА «ВЯЛОЙ КОЖИ»

Мекенбаева Р.Т. ${ }^{1}$, Марасулов Ш.И. ${ }^{1}$, Сарсембаева А.А. ${ }^{1}$, Нуркеев Б.А. ${ }^{1}$, Майоров Р.А. ${ }^{1}$, Байгожин Д.М. ${ }^{2}$, Мекенбаева Н.Б. ${ }^{3}$,

\section{Аксеитов А.M.}

'Детское кардиохирургическое отделение, Национальный научный медицинский центр, город Нур-Султан, Республика Казахстан

Отделение кардиологии, Национальный научный медицинский центр, город Нур-Султан, Республика Казахстан

${ }^{3}$ Медицинский университет Астана, город Нур-Султан, Республика Казахстан

\section{PEЗЮME}

В данной статье представлен клинический случай опыта катамнестического наблюдения за пациентом с врожденным пороком сердца в виде стеноза легочной артерии на фоне синдрома «вялой кожи». Показано, что возникновение врожденных пороков в большей степени зависит от наследственного фактора, которым, в данном случае, является родственный брак. Также стоит обратить внимание на то, что ассоциированный врожденный порок сердца: устьевой стеноз легочной артерии на фоне синдрома «вялой кожи» самопроизвольно купировался без хирургического вмешательства, что, вероятно, связано с особенностью течения фонового заболевания, то есть генерализованного эластолиза. Естественное течение данного врожденного порока сердца на фоне генетической патологии в виде синдрома «вялой кожи» указывает на положительное влияние патологического субстрата (гиперэластичности соединительной ткани) на состояние тканей сердца и сосудов. Несмотря на уже имеющиеся данные, все же трудно сделать прогноз течения данного заболевания. Для более лучшего понимания течения данного патологического процесса необходимо дальнейшее наблюдение за пациентом.

Ключевые слова: синдром вялой кожи, стеноз легочной артерии, врожденный порок сердца

\section{Актуальность}

Стеноз легочной артерии (СЛА) - это сужение просвета выносящего тракта правого желудочка. Патологические изменения затрагивают клапан легочной артерии или часть сосуда в области клапана. В 90\% случаев СЛА наблюдается именно клапанный стеноз легочной артерии. При данном ВПС легочный клапан имеет аномальное строение, например, бикуспидальный (двустворчатый) или диспластичный, как при синдроме Нунан. Инфундибулярный стеноз наблюдается крайне редко в сочетании с ДМЖП или тетрада Фалло. Надклапанный стеноз легочного ствола наблюдается при врожденной краснухе или при синдроме Вильямса, для которого характерны определенные черты лица (лицо эльфа), нарушение умственного развития, гиперкальциемия. Периферические стенозы легочного ствола, часто наблюдающиеся у новорожденных, представляют собой сужение ветвей легочных артерий, чаще на уровне бифуркации легочного ствола. Возникновение стеноза легочной артерии обусловлено первичным нарушением развития клапана, наблюдается сращение, утолщение, деформация створок клапана легочной артерии. Сопутствующие аномалии сердца, такие как дефект межпредсердной перегородки, открытый артериальный проток, могут усиливать анатомические изменения клапана и клиническую картину порока [1].

Согласно статистическим данным, изолированный стеноз ЛА наблюдается в 10\% случаев всех врожденных патологий сердца. Этиологическими факторами врожденных пороков сердца могут быть отягощенная наследственность, наличие других наследственных заболеваний, системных или метаболических заболеваний у матери, инфекционные заболевания матери на ранних сроках беременности, в частности, вирусные, прием некоторых медикаментов, имеющих побочные тератогенные эффекты, первые роды в возрасте более 38 лет, многоплодная беременность, экстракардиальные аномалии плода, хромосомные заболевания, нарушения фетоплацентарного кровотока, нарушения сердечного ритма плода, включая эпизодические[2].

В зависимости от локализации сужения сосуда выделяют надклапанный, клапанный, подклапанный стеноз легочной артерии. Различают комбинированную форму заболевания в случаях сочетания стенозов разной локализации самой ЛА или в сочетании с другими ВПС. Клапанная форма патологии диагностируется примерно у 90\% пациентов. Клапан легочной артерии у пациентов с врожденной патологией легочной артерии может иметь аномальное строение (одноили двустворчатые клапаны). Характерным для стеноза клапана является постстенотическое расширение ствола легочной артерии. Подклапанный стеноз характеризуется воронкообразным сужением сосуда или аномальным расположением мышечного пучка, препятствующим выбросу крови в легочный круг кровообращения. Изолированный подклапанный стеноз легочной артерии часто сочетается с дефектом межжелудочковой перегородки. Надклапанный стеноз часто встречается на фоне синдромов Вильямса и Нунана. Данная патология встречается в виде множественных периферических сужений, мембраны, локализованного сужения или диффузной гипоплазии. Размеры правого желудочка и трехстворчатого клапана у пациентов со СЛА обычно в пределах нормы. Стеноз легочной артерии затрудняет кровообращение, в результате чего возрастает градиент давления между правым желудочком и легочным кругом кровообращения. Патологическое строение выводящего отдела правого желудочка является причиной систолических перегрузок миокарда, которые со временем приводят к гипертрофии миокарда и правожелудочковой недостаточности [3]

Клинические проявления СЛА напрямую зависят от степени стеноза. Бессимптомное течение заболевания наблюдается при минимальном сужении ЛА, при котором градиент давления между правым желудочком и легочной артерией до 40 мм рт. ст. При средней степени стеноза ЛА данный градиент давления в пределах 40-70 мм рт. ст., наблюдаются повышенная утомляемость и одышка при физических нагрузках. Критический стеноз сопровождается симптомами сердечной недостаточности, вызванной праволевым сбросом крови через овальное окно, в виде цианоза и одышки, градиент давления свыше 70 мм рт. ст. [4].

Единственно эффективным способом лечения СЛА является хирургическое вмешательство - устранение стеноза. Оперативное лечение рекомендуется пациентам со средней степенью стеноза и критическим СЛА. Минимальный стеноз легочной артерии оперативному лечению не подлежит, иногда наблюдается самопроизвольное исчезновение стеноза. Хирургическая тактика зависит от степени стеноза и тяжести состояния пациента. Пациентам с критическим стенозом ЛА операция проводится в первые месяцы жизни. При средней степени СЛА сроки оперативного лечения - в 5-10 лет. Изолированный клапанный стеноз ЛА подразумевает применение вальвулопластики: эндоваскулярная баллонная или открытая вальвулопластика. Баллонная атриосептостомия требуется пациентам с критическим стенозом ЛА. При некоторых формах СЛА накладываются системно-легочные анастомозы. Реконструктивные операции с применением 
заплаты из аутоперикарда или ксеноперикарда проводят при надклапанном стенозе в области сужения [5].

\section{Описание случая}

Приводим данные собственного наблюдения пациента А. В возрасте 8 месяцев ребенок поступил в кардиохирургическую клинику в плановом порядке с жалобами, со слов матери, на частые простудные заболевания, бронхиты, одышку при нагрузке, цианоз, усиливающийся при плаче или беспокойстве. Фото представлены ниже, разрешение на фотосъемку и публикацию снимков взято у матери (Фото).
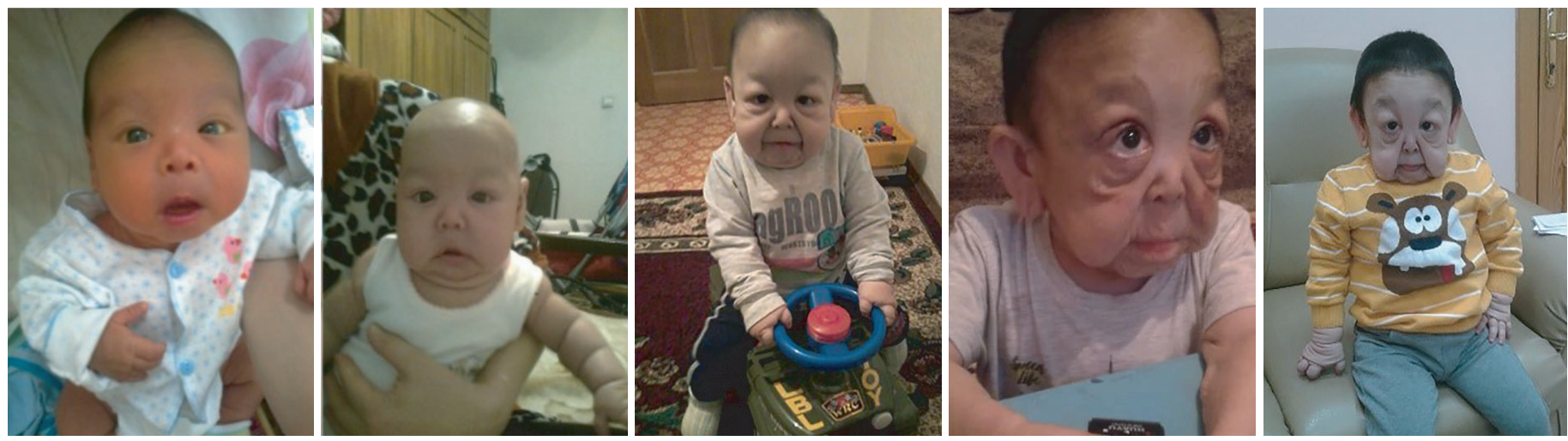

Из анамнеза жизни известно, что ребенок от 2 беременности, протекавшей без особенностей, 2 самостоятельных родов, на 36 гестационной неделе. Вес при рождении 3500 г, рост 53 см. Аллергоанамнез: со слов матери аллергических реакций не было, лекарственной непереносимости не отмечает. Первый ребенокумерв возрасте 8 месяцев от не верифицированного ВПС (документальных данных нет) на фоне синдрома «вялой кожи». Туб. контакт отрицает. В новорожденном возрасте ребенок прооперирован по поводу гипертрофированной формы пилоростеноза, тогда же был выставлен диагноз «ВПС. Стеноз легочной артерии умеренный. ООО. НК 0. Пахово-мошоночная грыжа справа. Конъюгационная желтуха. Перинатальная энцефалопатия гипоксически-ишемического генеза, подострый период. Судорожный синдром. ВУИ, генерализованная форма (ЦМВ, герпес, токсоплазмоз?). Врожденный гипотиреоз? Хондродистрофия?». В дальнейшем, спустя 3 месяца после пилоропластики, отмечался периодически сухой кашель, который носил навязчивый характер. Из перенесенных заболеваний - частые простуды, бронхиты. В феврале 2013 года находился на стационарном лечении по поводу пневмонии, осложненной бронхообструктивным синдромом в пульмонологическом отделении детского стационара. Консервативное лечение бронхообструктивного синдрома было неэффективным. Тогда же был выставлен диагноз «Фиброэластоз легких».

В динамике после консультации кардиохирурга, была рекомендована плановая госпитализация на оперативное лечение ВПС в кардиохирургическую клинику.

Клинический статус - при поступлении в нашу клинику состояние тяжелое за счет ВПС, фоновой патологии. Сознание ясное. Ребенок на осмотр реагирует спокойно. Правильного телосложения. Удовлетворительного питания. Рост 68 см, вес 8205-г. ППТ- 0,41. Кожные покровы бледные, свисает складками. Складчатость кожных покровов выражена на лице, в верхней части туловища, а также на коленях и запястьях; грудь и живот отвислые. Лицо имеет плачущее печальное выражение. Отмечается пастозность, тургор тканей снижен.

Периферические лимфатические узлы не увеличены. Зев спокойный, налетов нет. Дыхание через нос - свободное, ЧДД = 30 в 1 мин. Грудная клетка не изменена. Перкуторный звук над легкими: легочный. В легких дыхание жесткое, проводится по всем полям, хрипы проводные. Тоны сердца ритмичные, систолический шум над легочной артерией. АД 90/45. мм.рт.ст., ЧСС 130 уд/мин. Сатурация 97\%. Пульс удовлетворительный. Подкожные вены без особенностей. Пульсация периферических артерий удовлетворительная. Язык чистый, влажный. Живот участвует в акте дыхания, мягкий. Печень $+1,0$ см из-под края реберной дуги. Селезенка не увеличена. Физиологические отправления не нарушены. Мочеиспускание нормальное.

\section{Результаты лабораторно-инстру- ментальных исследований}

Лабораторные данные: общий анализ крови - лейкоцитоз до 10,5 с лимфоцитозом до $73 \%$, биохимический анализ крови - гипопротеинемия.

Микробиологические исследования: - высеяны Enterococcus durans $1 * 105$, Staphylococcus aureus $3 * 103$, дрожжевые грибки Candida.

ЭХОКГ - корень аорты 1,1 см, ЛА ствол 1,0 см, правая ветвь 0,29 см, левая 0,66 см. ЛЖ КДР 2,4см, КСР 1,3 см, ЛП апик. 2,0*2,3 см, КДО 7.4 мл, КСО 2,9 мл. ТЗСЛЖд $0,45 \mathrm{~cm}$, ТМЖПд $0.44 \mathrm{~cm}$. Правый желудочек 1,44cм, правое предсердие 2,0-2,2 см. Ускорен градиент у устья правой легочной артерии до 85 мм.рт.ст. Заключение: ВПС: Устьевой стеноз с гипоплазией правой ветви легочной артерии. Камеры сердца не увеличены. Насосная и сократительная функции ЛЖ удовлетворительные. ФВ 60\%. Гипертрофии миокарда нет. Трикуспидальная регургитация до 1 степени. Дополнительная апикальная хорда в полости левого желудочка.

ЭКГ - ритм синусовый с ЧСС 149 в минуту, ЭОС отклонена вправо, вертикальная позиция, признаки гипоксии миокарда, нарушения внутрижелудочковой проводимости по правой ножке пучка Гиса.

КТ ангиопульмонография: - на серии полученных КТ ангиограмм отмечаются выраженные артефакты сердечных сокращений. Определяется стенозирование правой легочной артерии до 2,8 мм, на протяжении до 7 мм от устья бифуркации и ближе к выходному тракту правого желудочка. Диаметр ствола ЛА до 7 мм. Диаметр ПЛА - до 4,7 мм. Диаметр ЛЛА - до 5 мм. Диаметр дуги аорты до 6 мм. Диаметр нисходящего отдела грудной аорты до 5,5-6,0 мм. Заключение: КТАкартина стеноза (гипоплазии?) устья правой ветви легочной артерии. 
КТ легких- картина легочной гипертензии, с явлениями пневмонита.

Учитывая анамнестические данные (родственный брак, у 1 ребенка (девочка) имелся ВПС на фоне синдрома «вялой кожи», в 8-месячном возрасте ребенок умер), фенотипические признаки, свидетельствующие о патологии соединительной ткани, в частности, кожи («скорбный вид», крючковатый нос, множество кожных складок на лице, туловище и конечностях, низкий дребезжащий голос, висячие уши и т.д.), наличие врожденной патологии ЖКТ (пилоростеноз), патологии легких (фиброэластоз), решено было провести повторную консультацию генетика, который изначально исключил хромосомную патологию и заподозрил хондродистрофию. При повторной консультации генетика диагноз «Синдром «вялой кожи» был подтвержден, соответственно диагноз «Хондродистрофия» был снят.

Учитывая клинику заболевания (одышка, слабость), наличие ВПС в виде умеренного клапанного стеноза легочной артерии, сопутствующего заболевания (фиброэластоз легких), фоновой генетической патологии в виде синдрома «вялой кожи» было решено - воздержаться от оперативного лечения с последующим регулярным диспансерным наблюдением. Ребенок был выписан по месту жительства.

\section{Обсуждение}

Динамическое наблюдение кардиолога за состоянием ребенка в амбулаторных условиях в течение 6 лет показало, что имеется положительная динамика показателей ЭХОКГ (Таблица 1).

Таблица 1 Динамическая картина ЭХОКГ-показателей у пациента А. в катамнезе (в течение 6 лет)

\begin{tabular}{|c|c|c|c|}
\hline & Group I $(\mathrm{n}=21)$ & Group II $(\mathrm{n}=19)$ & p-value \\
\hline Age (years) & $52.76 \pm 10.5$ & $56.57 \pm 13.29$ & $0.588 *$ \\
\hline \multicolumn{4}{|l|}{ Gender } \\
\hline Female & 13 (61.9) & $11(57.9)$ & \multirow[t]{2}{*}{$0.796^{* *}$} \\
\hline Male & $8(38.1)$ & $8(42.1)$ & \\
\hline BMI $(\mathrm{kg} / \mathrm{m} 2)$ & $27.8 \pm 4.17$ & $28.13 \pm 3.14$ & $0.774^{*}$ \\
\hline \multicolumn{4}{|l|}{ Level of Education } \\
\hline Illiterate & 3 (14.3) & $4(21.1)$ & \multirow{5}{*}{$0.842^{* *}$} \\
\hline Primary & $10(47.6)$ & $8(42.1)$ & \\
\hline Secondary & $2(9.5)$ & $2(10.5)$ & \\
\hline High school & $3(14.3)$ & $4(21.1)$ & \\
\hline University & 3 (14.3) & $1(5.3)$ & \\
\hline $\begin{array}{l}\text { Duration of disease } \\
\text { (months) }\end{array}$ & $55.6 \pm 44.4$ & $36.7 \pm 27.0$ & $0.101^{*}$ \\
\hline \multicolumn{4}{|l|}{ Chronic disease } \\
\hline No & 7 (33.3) & $8(42.1)$ & \multirow[t]{2}{*}{$0.567^{* *}$} \\
\hline Yes & 14 (66.7) & $11(57.9)$ & \\
\hline \multicolumn{4}{|l|}{ Orthosis use } \\
\hline No & $13(40.6)$ & $11(34.4)$ & \multirow[t]{2}{*}{$0.784^{* *}$} \\
\hline Yes & 19 (59.4) & $21(65.6)$ & \\
\hline
\end{tabular}

*Mann-Whitney U test

**Chi-square test

При анализе данных, представленных в таблице, видно, что имеется положительная динамика клинической картины СЛА.

В настоящее время ребенок наблюдается у эндокринолога с диагнозом: «Врожденный гипотиреоз». Получает L-тироксин по 50 мг 1 раз в день с 5 месяцев. Кроме того, ребенок состоит на Д-учете у пульмонолога по поводу бронхиальной астмы на фоне фиброэластоза легких.

\section{Заключение}

В этиологии врожденных пороков сердца определенно имеют значение три основных фактора: генетическое наследование порока; воздействие факторов среды, оказывающих патологическое влияние на эмбриогенез с формированием эмбрио- и фетопатий; сочетание наследственной предрасположенности и патологического влияния различных факторов среды. Генетическое наследование порока может быть обусловлено как количественными и структурными хромосомными аберрациями (5\%), так и мутацией одиночного гена (2-3\%). Роль наследственно-генетического фактора доказывают случаи наличия врожденных пороков сердца у нескольких членов одной семьи (что имело место в данном клиническом случае, и подтверждает наследование по аутосомнодоминантному типу), а также у родственников 2-й и 3-й степени родства [6].

У нашего пациента имеет место «синдром вялой кожи», который является генетически детерминированным синдромом, ассоциированным с врожденными пороками развития внутренних органов: пилоростеноз, фиброэластоз легких, ВПС в виде устьевого стеноза легочной артерии. Уникальность данного клинического случая заключается в том, что стеноз ЛА самопроизвольно купировался. Возможно, такая динамика клинической картины СЛА связана с основной генетической патологией, заключающейся в гиперэластичности соединительной ткани. Немаловажную роль для гемодинамики в бассейне легочной артерии имеет фиброэластоз легких у данного пациента. Для адекватной оценки состояния сосудов легочной артерии и сердца в настоящий момент необходимо детальное обследование пациента в стационарных условиях с проведением КТАисследования и, при необходимости, зондирования полостей сердца и сосудов. Однако, родители ребенка отказываются от стационарного обследования. Решено продолжить катамнестическое наблюдение за пациентом в амбулаторных условиях.

Disclosures: There is no conflict of interest for all authors.

Patient informed consent: obtained. 


\section{Литература}

1. Belozerov Yu.M. Detskaya kardiologiya (Pediatric Cardiology) [in Russian]. MEDpress-Inform, 2004; 159.

2. Amosov N.M. Bendet Ya.A. Terapevticheskiye aspekty kardiohirurgii (Therapeutic Aspects of Heart Surgery) [in Russian]. Health. $1990 ; 228$.

3. V.N. Zaporozhan, I.L. Babiy, S.R. Galich. Vrojdennyye poroki (Congenital malformations) [in Russian]. Odessa: ONMEDU. 2012; 320.

4. Krivoshchekov E.V., Kovalev I.A., Shipulina V.M. Vrojdennyye poroki serdca (Congenital heart defects) [in Russian]. Tomsk: SST2009; 48.

5. Mutafyan O.A. Vrojdennyye poroki serdca u detei (Congenital heart defects in children) [in Russian]. Nevsky Dialect. $2002 ; 215$.

6. Mutafyan O.A. Vrojdennyye poroki serdca u detei (Congenital heart defects in children) [in Russian]. Nevsky Dialect. $2002 ; 218$.

How to cite this article: Rackhima Mekenbayeva, Shukhrat Marassulov, Anar Sarsembayeva, Bakhytzhan Nurkeyev, Rinat Maiorov, Daniyar Baigozhin, Nigina Mekenbayeva, Arman Akseitov A.M. The monitoring experience of a congenital heart disease patient with pulmonary artery stenosis and «sluggish skin» syndrome [in Russian]. J Clin Med Kaz. 2019; 2(52):63-67 